\title{
Cape clawless otter conservation and a trout river in Zimbabwe: a case study
}

\author{
James Butler
}

\begin{abstract}
A community-based conservation scheme on the upper catchment of the Kairezi River, eastern Zimbabwe, has been based on financial returns from trout fishing. Despite consistent stocking, trout catches have been declining, which undermines the justification for conservation. Fishery managers believed that Cape clawless otters Aonyx capensis preyed on trout and competed with them for food. An analysis of otter and trout diets in 1993 indicated that this was not the case and the otter was not the cause of the lack of trout. The future of the scheme and the conservation of otters in the catchment are more likely to be threatened by poaching and uncontrolled agricultural activities.
\end{abstract}

\section{Introduction}

The conservation and sustainable use of wildlife resources in Zimbabwe is spearheaded by the CAMPFIRE (Communal Areas Management Programme for Indigenous Resources) concept, which enables impoverished rural communities to benefit from the financial returns generated by the exploitation of wildlife that they own. This gives the local communities an incentive to conserve and use their wildlife sustainably so that the potential for future revenue generation is retained (Peterson, 1991). CAMPFIRE projects are based on safari hunting or game viewing enterprises in areas where wildlife is plentiful (Child and Peterson, 1991). The Nyanga area of the eastern highlands is less suited to these types of use because densities of large game species are naturally low. However, this scenic mountainous region has perennial rivers in which rainbow trout Oncorhyncus mykiss have been introduced. Trout fishing in the Nyanga National Park is a popular recreation and has contributed to the park becoming the most popular resort in Zimbabwe. This form of sport may represent an alternative option for CAMPFIRE schemes in the eastern highlands.

In 1988 the Zimbabwe Government purchased the Kairezi River catchment adjacent to the Nyanga National Park to establish a resettlement scheme in the villages of Dazi, Nyafaru and Nyamutsapa (Figure 1) for people who had been evicted during the Independence War (1970-78; Anon., 1988a). Anticipating the problems typical of other resettlement schemes, which rely on subsistence agriculture (overgrazing, fuelwood cutting, erosion and siltation), the Department of National Parks and Wildlife Management (DNPWLM) suggested that a CAMPFIRE scheme could be established to conserve the catchment, which serves as an important water supply for similar settlements further downstream (Anon., 1988b). Because trout already existed in the river, it was suggested that resettled families could generate income from the sale of fishing rights. At the same time a conservation corridor would be established along the river course in which agricultural activity and human settlement would be strictly controlled to minimize erosion and siltation, and ensure the future viability of the fishery.

The plan was agreed in the same year and the Kairezi River Protected Area (KRPA), covering 1645 ha along $7 \mathrm{~km}$ of the river course, was established (Figure 1). The fishing rights were sold to the Nyanga Downs Fly Fishing Club (NDFFC), which donates a percentage of its annual revenue to the local community. The KRPA is managed jointly by the club and 

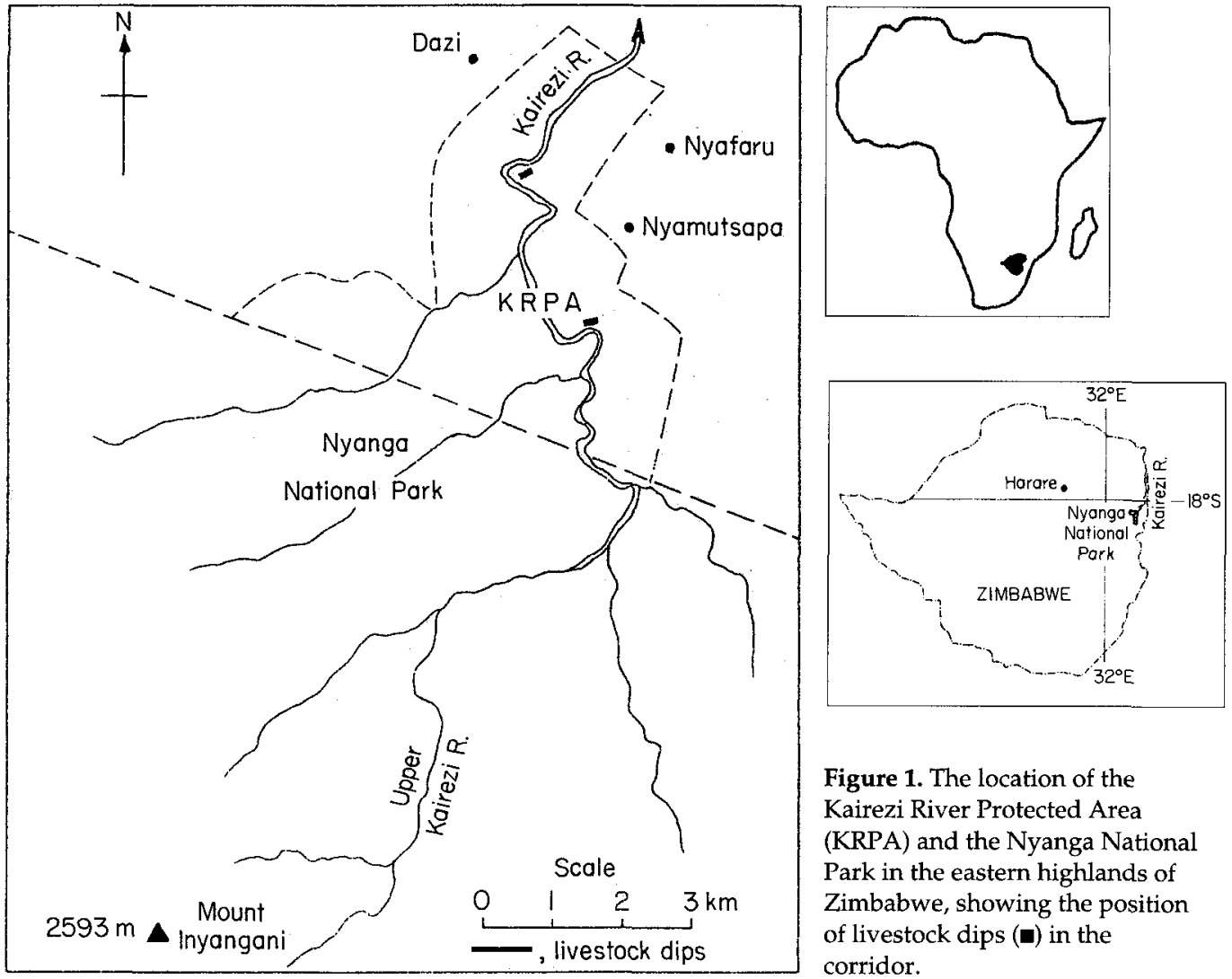

Figure 1. The location of the Kairezi River Protected Area (KRPA) and the Nyanga National Park in the eastern highlands of Zimbabwe, showing the position of livestock dips ( $\square$ ) in the corridor.

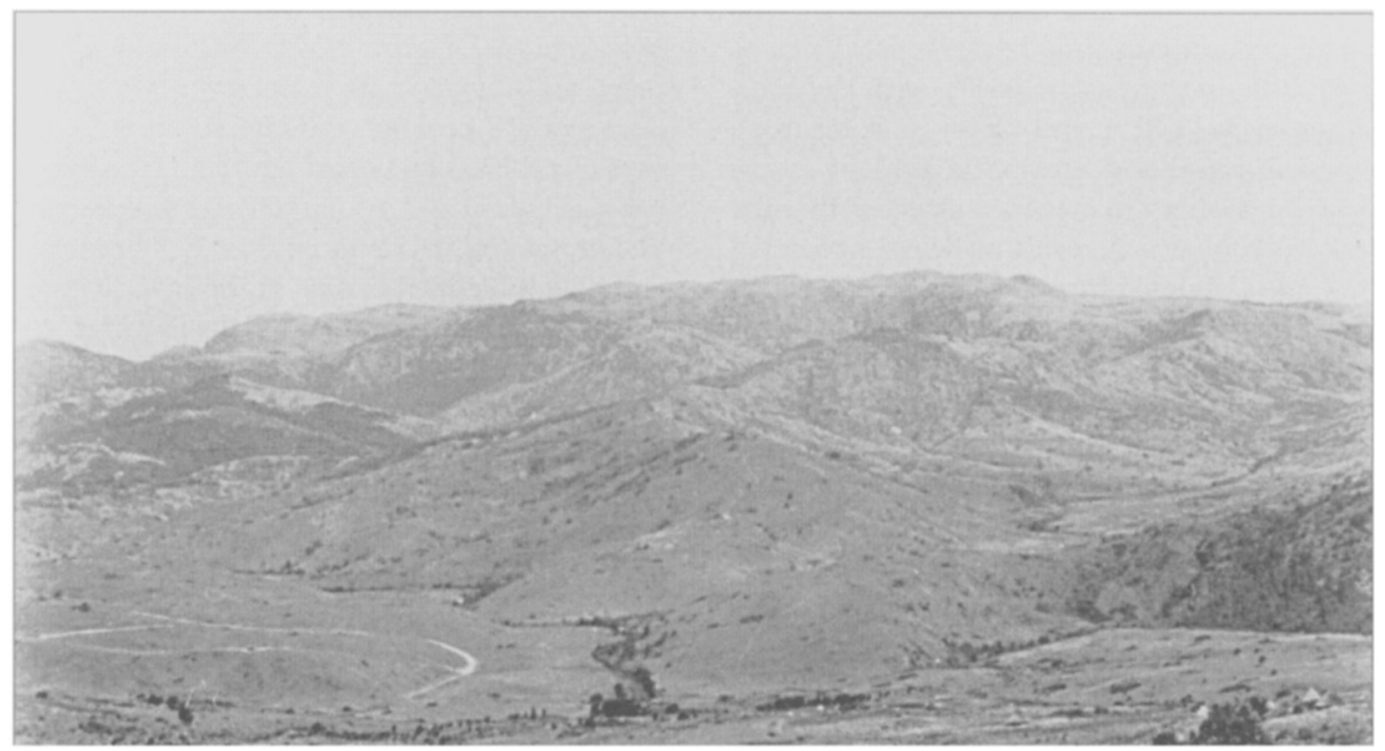

A view of the Kairezi River catchment looking upstream, with Mt Inyangani and the Nyanga National Park in the background and the Kairezi River Protected Area in the foreground (James Butler). 


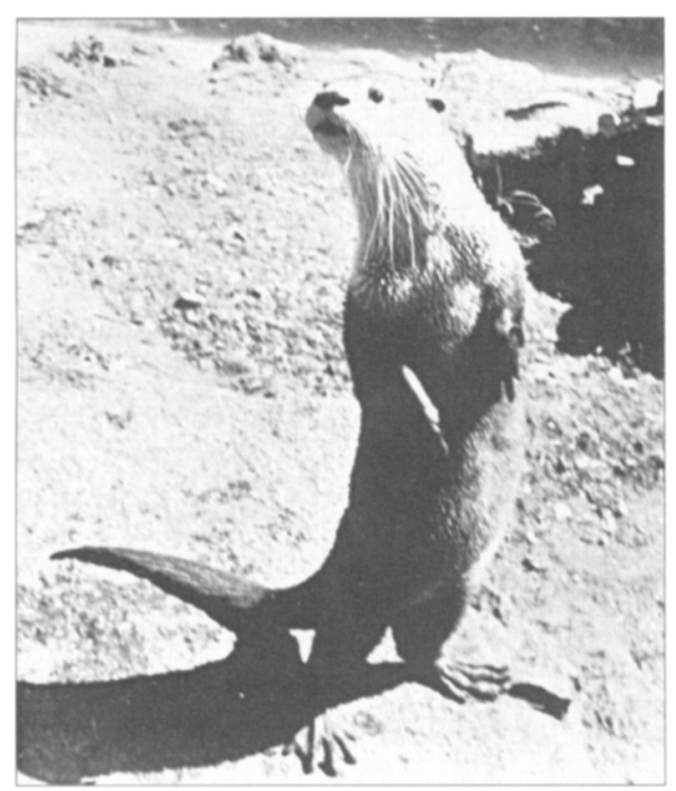

Cape clawless otter (James Butler).

the KRPA Steering Committee, which is made up of community leaders.

However, trout catches have declined since 1988, despite regular restocking, which has discouraged the club's members from visiting the river. Consequently, its membership and revenue has fallen and generated little income for the community. As a result local farmers have little incentive to comply with the principles of the KRPA and heavy grazing, fuelwood removal and erosion is evident in the corridor. Fishery managers suspected that the lack of trout was a result of heavy predation by Cape clawless otters Aonyx capensis, which may also compete with them for food.

Little is known about the distribution and conservation status of the clawless otter in Zimbabwe, but it is assumed that it occurs wherever there are permanent bodies of water (Rowe-Rowe, 1991). In commercial farming areas the construction of small dams may have provided favourable conditions for otters (Rowe-Rowe, 1991). However, in areas of subsistence agriculture, the species is probably threatened by the degradation of catchments resulting from the growing human population and demands for land and water (Gibson,
1991), a factor that may constrict the distribution of otter species throughout Africa in the long term (Rowe-Rowe, 1990). Only the smallest protected areas in Zimbabwe, such as the Nyanga, Chimanimani and Matobos National Parks, contain suitable otter habitat, and the bulk of the country's otter population probably exists outside these areas. Therefore, catchment conservation schemes on rivers such as the Kairezi would be a way of simultaneously protecting valuable water resources and otter habitat, as recommended by the IUCN/SSC Otter Specialist Group (RoweRowe, 1990).

In assessing the alleged otter problem within the KRPA and identifying other possible causes of the KRPA's faltering progress, this paper presents a case study of a catchment conservation scheme and the practical limitations of such projects. Recommendations are made that may assist in the future management of the scheme.

\section{The study area}

The Kairezi River rises at an altitude of $2500 \mathrm{~m}$ on the plateau of Mount Inyangani within the Nyanga National Park and flows north-east to become the Zimbabwean border with Mozambique (Figure 1). In the upper catchment the river and its major tributaries flow over granite geology and the river bed consists of pebbles, rocks and boulders. The water has a $\mathrm{pH}$ of 7.3 and a conductivity of $36 \mu \mathrm{Scm}^{-1}$. The annual rainfall is more than $1700 \mathrm{~mm}$ and is highly effective because of the low air temperatures. The vegetation of the Nyanga region is typical of the Afromontane biome with open wooded grassland and denser thickets along the watercourses (White, 1983).

\section{Methodology}

Between January and June 1993, 255 otter faeces (scats) were collected from $7 \mathrm{~km}$ of the Kairezi River and its tributaries within the KRPA and $2 \mathrm{~km}$ of the river's course immediately upstream, within the Nyanga National 
Park. Scats were air-dried and their contents analysed. The indigestible remains of food items found in scats were identified from a reference collection of possible prey species found in the study area, according to methods in Rowe-Rowe (1977). Unidentifiable remains were analysed by the Natural History Museum, Bulawayo. Forty trout were caught on rod and line and their stomach contents analysed according to Elliot (1967). Insects were identified from Skaife (1953). The importance of the food items in each animal's diet was estimated by the relative percentage frequency of occurrence (\%RF; Rowe-Rowe, 1977). Dietary overlap was calculated by the proportional similarity method (Pielou, 1977).

Open-ended interviews were carried out among 32 members of the local community living adjacent to the corridor and with the managers of the Nyafaru trout farm to assess their perceptions of the problems of the KRPA. They were also asked about the role of otters and to what degree they are considered a pest.

\section{Results}

Trout remains were found in six of the scats, constituting 1 per cent of the otter diet (Table 1). River crabs, catfish, frogs and dragonfly nymphs were the most important prey items and together comprised 93.6 per cent of the diet. In comparison, trout fed on a wide variety of aquatic and terrestrial insects (Table 2). The important prey types that were shared by each species were crabs and nymphs of the dragonfly Anax imperator, and each occurred more frequently in the diet of otters than that of trout (41.9 per cent vs. 7.4. per cent for crabs; 11.8 per cent vs. 6.8 per cent for dragonfly nymphs). The proportional similarity between their diets was 17 per cent.

Local inhabitants revealed that poaching had been taking place, particularly during the drought year of 1991/92 when the season's crop failed, and that a poison obtained by crushing tubers of certain plants was used to kill the fish. The Nyafaru trout farm manager suspected that the natural tendency of rain

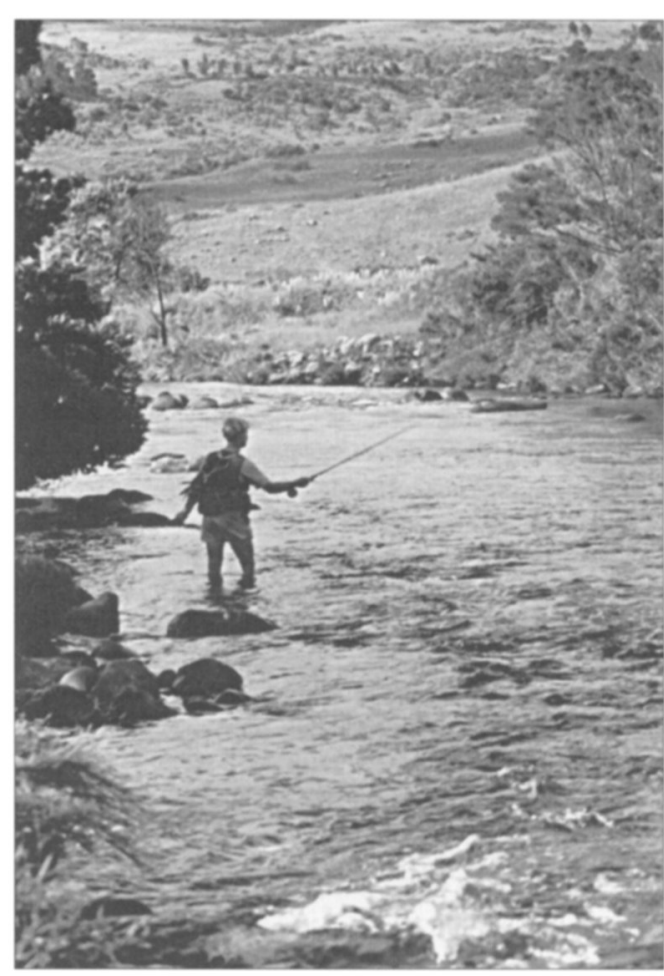

Trout fishing in the Kairezi River (Johan du Toit).

bow trout to migrate may have been responsible for the disappearance of stocked fish, either upstream into the national park or downstream, where the water is too warm for them to survive. Livestock are dipped weekly during the wet season and fortnightly during the dry season at two sites within the KRPA (Figure 1). The organophosphate dip is diluted and is allowed to soak away into the river after use. Dipping began at this frequency in 1988 when the resettlement scheme was established.

Erosion was evident within the corridor, particularly along livestock paths. During rain these tracks formed rivulets, which carried soil into the river, discolouring the water for several days at a time, while the water upstream of the KRPA remained clear. Overgrazing was only obvious in the meadows along the river's course, and not on the steep valley sides. During the study, trees and larger bushes along the river were regularly removed for fuelwood by local inhabitants. 
Food type

River crab, Potamon perlatus

Mountain catfish, Amphilius uranoscopus

Dragonfly nymph, Anax imperator

Common river frog, Rana angolensis

Ruminant dung

Mottled eel, Anguilla bengalensis

Dung beetles, Onitis, Diastellopalpus spp.

Rainbow trout, Oncorhyncus mykiss

Locusts, Acrididae

Vlei rat, Otomys irroratus

Grasshoppers, Tettigonioidea

Shield bugs, Pentatomidae

Herald snake, Crotaphopeltis hotamboeia

Brown water snake, Lycodonomorphous rufulus

Dragonfly nymphs, Libellulidae

Moth adults, Sphingidae

Caterpillars, Lepidoptera

Soldier termites, Termitidae

Earwigs, Forficulinae

Common toad, Bufo regularis

Masked weaver, Ploceus velatus

Dragonfly adult, Anax imperator

\begin{tabular}{rr}
\multicolumn{2}{l}{ Occurrence } \\
\hline Actual & $\%$ RF \\
\hline 255 & 41.9 \\
115 & 18.9 \\
72 & 11.8 \\
67 & 11.0 \\
29 & 4.8 \\
19 & 3.1 \\
13 & 2.1 \\
6 & 1.0 \\
6 & 1.0 \\
5 & 0.8 \\
4 & 0.7 \\
4 & 0.7 \\
2 & 0.3 \\
2 & 0.3 \\
2 & 0.3 \\
1 & 0.2 \\
1 & 0.2 \\
1 & 0.2 \\
1 & 0.2 \\
1 & 0.2 \\
1 & 0.2 \\
1 & 0.2 \\
\hline
\end{tabular}

Table 1. Results of the analysis of 255 clawless otter scats collected from the Upper Kairezi River between January and June 1993
None of the people interviewed considered otters to be major predators of trout in the river, but since 1988 the Nyafaru trout farm claimed to have trapped and killed between three and eight animals that had been raiding their ponds and killing fish. Several households close to the river complained that otters killed domestic poultry at night. Despite this, they are not hunted because they are considered to be too difficult to catch with dogs and dangerous if held at bay. The meat is considered to be of no value, but the face oils of trapped animals are used in traditional medicine as a fertility enhancement, and the pelt is regarded as a luxury.

\section{Discussion and recommendations}

The presence of so few trout in the diet of the Kairezi otters indicates that they do not prey heavily on trout, as Rowe-Rowe (1977) noted in Natal, South Africa. This is probably because clawless otters are adapted to catching prey by feel on the river-bed with their sensi- tive, fingered 'hands', unlike piscivorous species such as the spotted-necked otter Lutra maculicollis, which hunt by sight and catch prey in their mouths (Rowe-Rowe. 1977). Consequently, clawless otters are better adapted to catch bottom-dwelling fish such as catfish and eels (Table 1) rather than swift, mid-water species like trout. The dissimilarity of the otter and trout diets indicates that competition between them is unlikely to limit the food available for trout and therefore their numbers. Competition is probably further minimized because the otters catch prey on the river bed while trout feed on drifting invertebrates carried by the current (Elliot, 1967). Therefore it seems highly unlikely that otters are the cause of the disappearance of trout in the KRPA.

The decline of trout is more likely to be explained by a combination of other factors. The extent of poaching could not be quantified, but common sense suggests that impoverished families in the recent drought were unlikely to ignore a ready supply of trout, particularly as they theoretically owned them. 
The loss of stocked trout by migration seems to be a problen about which little can be done. Although the influence of organophosphate pollution is not known, it may not be a coincidence that trout numbers have only declined since 1988 when the dipping policy began. The organophosphate dips are powerful insecticides and their continual discharge into the river must affect the populations of aquatic insects. The influence of the effluent on the aquatic food chain should be investigated, and plans should be made to relocate the dips outside the KRPA. The latter recommendation should be followed if only to focus livestock activity away from the corridor, as the original proposal suggested (Anon., 1988a).

The problems of poaching, erosion and vegetation removal, and the potential for chemical pollution, are likely to increase because the human population in the catchment is growing rapidly, which is typical of all rural areas of Zimbabwe. To solve the problems, a greater financial incentive is needed for the local population to comply with the original principles of the KRPA. Since 1988 the NDFFC has generated only $\$ Z 6000$ for a population of 193 families. With falling membership the club's ability to provide greater amounts annually will further diminish. To supplement this revenue the Steering Committee should consider seeking assistance from non-governmental organizations, which could invest capital into further tourism enterprises and take advantage of the established popularity of the Nyanga area. Concurrently, livestock numbers need to be monitored and grazing both inside and outside the corridor should be carefully controlled, while some form of restriction on fuelwood cutting along the river is also required to prevent bank erosion, siltation and the destruction of potential otter denning sites.

It seems that, apart from those animals killed at Nyafaru trout farm, the clawless otter population of the Upper Kairezi catchment is not immediately threatened. If the removal of vegetation along the river continues, however, the population may be restricted by habitat availability to the national park. The IUCN
Otter Specialist Group recommend that catchment conservation measures, including the control of subsistence agricultural methods,

Table 2. Results of the analysis of the stomach contents of 40 rainbow trout caught in the Upper Kairezi River between February and June 1993

\begin{tabular}{|c|c|c|}
\hline \multirow[b]{2}{*}{ Food type } & \multicolumn{2}{|c|}{ Occurrence } \\
\hline & Actual & $\%$ RF \\
\hline Mayfly nymphs, Baetis harrisoni & 31 & 10.0 \\
\hline Mayfly nymphs, Ecdyonuridae & 30 & 9.7 \\
\hline Ants, Formicidae & 28 & 9.1 \\
\hline Caddis larvae, Hydropsychidae & 25 & 8.1 \\
\hline River crab, Potamon perlatus & 23 & 7.4 \\
\hline Dragonfly nymphs, Anax imperator & 21 & 6.8 \\
\hline Dragonfly nymphs, Libellulidae & 14 & 4.5 \\
\hline Whirligig beetles, Gyrinidae & 11 & 3.6 \\
\hline Ground beetles, Carabidae & 9 & 3.0 \\
\hline Dragonfly nymphs, Gomphidae & 8 & 2.6 \\
\hline Simuliidae adults & 8 & 2.6 \\
\hline Chironomidae adults & 7 & 2.3 \\
\hline Wasps, Eumenidae & 7 & 2.3 \\
\hline House flies, Muscidae & 7 & 2.3 \\
\hline Diving beetles, Dysticidae & 6 & 2.0 \\
\hline Locusts, Acrididae & 6 & 2.0 \\
\hline Shield bugs, Pentatomidae & 5 & 1.6 \\
\hline Caddis pupae, Hydropsychidae & 5 & 1.6 \\
\hline Mayfly nymphs, Brachycercidae & 4 & 1.3 \\
\hline \multicolumn{3}{|l|}{ Mountain catfish, } \\
\hline Amphilius uranoscopus & 4 & 1.3 \\
\hline Wood, feathers & 4 & 1.3 \\
\hline Stonefly nymphs, Perlidae & 4 & 1.3 \\
\hline Damselfly adults, Chlorolestidae & 4 & 1.3 \\
\hline Caterpillars, Lepidoptera & 4 & 1.3 \\
\hline Simuliidae larvae & 3 & 1.0 \\
\hline Carder bees, Megachilidae & 3 & 1.0 \\
\hline Dragonfly adults, Anax imperator & 3 & 1.0 \\
\hline Caddis pupae, Hydroptilidae & 3 & 1.0 \\
\hline Grasshoppers, Tettigonioidae & 3 & 1.0 \\
\hline Mayfly imagos, Baetis harrisoni & 2 & 0.6 \\
\hline Mayfly subimagos, Brachycercidae & 2 & 0.6 \\
\hline Wasps, Ichneumenoidae & 2 & 0.6 \\
\hline Water beetle larvae, Dyropidae & 2 & 0.6 \\
\hline Termites, Termitidae & 2 & 0.6 \\
\hline Caddis larvae, Hydroptilidae & 1 & 0.3 \\
\hline Honey bees, Apidae & 1 & 0.3 \\
\hline Mayfly nymphs, Ephemerellidae & 1 & 0.3 \\
\hline Click beetles, Elateridae & 1 & 0.3 \\
\hline Dung beetles, Scarabaeinae & 1 & 0.3 \\
\hline Froghoppers, Cercopidae & 1 & 0.3 \\
\hline Caddis larvae, Leptocercidae & 1 & 0.3 \\
\hline Aphids, Aphidae & 1 & 0.3 \\
\hline Backswimmers, Notonectidae & 1 & 0.3 \\
\hline
\end{tabular}


should be introduced if African otter populations are to survive (Rowe-Rowe, 1990), and this is the case on the Kairezi. Furthermore, as dominant predators in aquatic ecosystems, otter species world-wide are useful indicators of the health of the wetlands that they inhabit (Foster-Turley, 1990). It is therefore possible that if the KRPA clawless otter population were monitored, it could act as an early-warning system for the effects of siltation and organophosphate pollution. If the managerial problems of the KRPA can be solved the scheme could provide a model for similar CAMPFIRE-type projects in other montane regions of Africa where catchment and otter conservation are priorities.

\section{Acknowledgments}

Funds for this research were supplied by the World Wide Fund for Nature (WWF) and the International Union for Conservation of Nature (IUCN) offices in Harare. The Department of National Parks and Wildlife Management allowed sampling to be undertaken in Nyanga National Park and the Nyanga District Council gave permission for work to be done in the KRPA. Professor B. Marshall of the Department of Biological Sciences, University of Zimbabwe, offered constructive criticism of the manuscript. Duncan Butler was an invaluable assistant.

\section{References}

Anon., 1988a. Kairezi Extension Intensive Resettlement Report. Department of Agriculture, Technical and Extension Services (AGRITEX), Harare, Zimbabwe (unpublished).

Anon., 1988b. Kairezi River Protected Area: Proposal to Accompany AGRITEX Kairezi Extension Intensive Resettlement Report. Department of National Parks and Wildlife Management, Harare, Zimbabwe (unpublished).

Child, B. and Peterson, J.H. 1991. CAMPFIRE in Rural Development: the Beitbridge Experience. Branch of Terrestrial Ecology, Department of National Parks and Wildlife Management, and Centre for Applied Social Sciences, University of Zimbabwe, Harare.

Elliot, J.M. 1967. The food of trout (Salmo trutta) in a Dartmoor stream. J. Appl. Ecol. 4, 59-71.

Gibson, D. St C. 1991. The status and distribution of small carnivores in Zimbabwe. Annex 8 in: Protected Species of Animals in Zimbabwe. Department of National Parks and Wildlife Management, Harare, Zimbabwe.

Foster-Turley, P. 1990. Introduction and overall recommendations. In Otters: An Action Plan for their Conservation (eds P. Foster-Turley, S. M. Macdonald and C. Mason), pp. 1-3. IUCN Species Survival Commission, Gland, Switzerland.

Peterson, J.H. 1991. A proto-CAMPFIRE initiative in Mahenya Ward, Chipinge District: development of a wildlife utilisation programme in response to community needs. Centre for Applied Social Sciences Occasional Paper Series-NRM: 3/1992. University of Zimbabwe, Harare.

Pielou, E.C. 1977. Mathematical Ecology. John Wiley and Sons, Chichester.

Rowe-Rowe, D.T. 1977. Food ecology of otters in Natal, South Africa. Oikos, 28, 210-219.

Rowe-Rowe, D.T. 1990. Action plan for otters. In Otters: an Action Plan for their Conservation (eds P. Foster-Turley, S. M. Macdonald and C. Mason), pp. 41-51. IUCN Species Survival Commission, Gland, Switzerland.

Rowe-Rowe, D.T. 1991. Status of otters in Africa. In Proceedings of the 5th Otter Colloquium (eds C. Reuther and R. Röchert), pp. 15-20. Habitat 6, Hankensbüttel.

Skaife, S.H. 1953. African Insect Life. Longmans Green, London.

White, F. 1983. The Vegetation of Africa. UNESCO, Paris.

J. R. A. Butler, Department of Biological Sciences, University of Zimbabwe, PO Box MP 167, Mount Pleasant, Harare, Zimbabwe. 